\title{
Suffix -mente adverbs in DAELE, a Spanish learners' dictionary ${ }^{1}$
}

\author{
Sergi Torner: Universitat Pompeu Fabra (sergi.torner@upf.edu)
}

\begin{abstract}
This paper looks at how Spanish - mente adverbs are shown in DAELE, an electronic dictionary for advanced-level students of Spanish, currently being developed at the Universitat Pompeu Fabra (Barcelona). Since a learners' dictionary is a tool conceived not only for decoding but also for production, information about use is deemed highly relevant in this dictionary. That is why new ways to provide adverb-production information are explored. Our discussion considers aspects of both the macrostructure and the microstructure. In terms of the macrostructure, the main problem arising from the lexicographical representation of adverbs ending in -mente is to decide which adverbs are to be included in the dictionary. In the Spanish lexicographical tradition there are several answers to this question, which range from including only a few adverbs to including all documented adverbs. In terms of the microstructure, it is important to provide all the semantic, morphosyntactic and pragmatic information on how to use an adverb, by means of a set of definition formulae which are both user friendly and informative.
\end{abstract}

\section{Introduction}

This paper discusses how Spanish - mente adverbs are dealt with in the learners' dictionary DAELE (Diccionario de Aprendizaje del Español como Lengua Extranjera). DAELE is an electronic dictionary for advanced students of Spanish that is currently being developed at the Universitat Pompeu Fabra (Barcelona). There are not many Spanish monolingual learners' dictionaries, and none of them have been originally conceived as an electronic tool, so DAELE is an innovative project in the Spanish lexicographical landscape. At present, its mission is to test new ways of providing information in this kind of dictionary. Unlike so many current Spanish dictionaries the DAELE dictionary aims to be a useful electronic tool for language production rather than only for decoding. To that end, we are currently working on a prototype, which includes a core Spanish vocabulary of about 7,000 words. ${ }^{2}$

Presenting adverbs in dictionaries is a challenge that has been little explored by theoretical lexicography, and for which practical lexicography has given many different, but not always particularly consistent, answers. The principles that govern the use of adverbs are shared by many languages (Cinque 1999 for example), even though each language may also display certain idiosyncrasies. Dictionaries therefore need to provide answers to very similar problems, which stem from these shared principles, regardless of the language involved. An example of this is the issue of how to explain pragmatic features. Another one is how to make certain grammatical restrictions explicit. And this can be done even if the specific description of each item is different. This paper focuses on Spanish adverbs, but it tackles issues that should be addressed in one way or another in dictionaries of any language aiming to explain how its adverbs are used. Specifically, there is a discussion on the main difficulties involved in lexicographically dealing with -mente adverbs, which can be summed up in the following four points. 
a) Lemmatization. Since these adverbs are lexical units formed by a morphological process that is highly regular, lexicographers must decide whether or not to include all possible adverbs or only those which raise doubts among users.

b) Semantic relationship to adjectival bases. Spanish -mente adverbs are formed from adjectives. The semantics of adjectives is very complex because adjectives are highly polysemous words. For this reason, dictionary definitions of adverbs should be related to the corresponding meanings of the adjectival bases they derive from.

c) Definitions. Up to now, Spanish dictionaries have generally neglected problems in the definitions of -mente adverbs, usually reducing them to uninformative formulae, mainly 'de un modo + Adj' 'in an Adj manner', which do not reflect the diversity of meanings that adverbs can have.

d) Grammar and use. The last few decades of studies in linguistics have been fruitful in the area of adverbial grammar and use. Nevertheless, lexicographical theory has not yet explored the way to reflect this linguistic information in dictionary entries.

The answers that Spanish lexicographical praxis has given to these issues derive, to a large extent, from considerations that are unrelated to lexicographical theory, but rather have to do with factors such as an understanding of the nature of dictionaries, their function or coverage, as well as Spanish lexicographical tradition.

This paper argues for the options and criteria used in DAELE in relation to these four issues. The proposals herein apply particularly to non-native learners' dictionaries which are aimed primarily at encoding. Some of DAELE's options might also be valid for general Spanish dictionaries. Section two introduces the main challenges involved in representing adverbs in dictionaries. Section three offers a detailed discussion of problems to do with macrostructure-lemmatization and relationship to adjective bases - and there is further discussion on the solutions provided by DAELE. Section four discusses problems of the microstructure and the representation of grammatical and pragmatic information in lexicographical entries.

\section{The challenge of dealing with adverbs in dictionaries}

As has been discussed previously (see Corbin 1982, De Cesare 2003, Martínez Marín 2006, Perdiguero 2006, among others), adverbs make up a grammatical category which has not been dealt with satisfactorily in dictionaries. This is largely due to the fact that lexicographical descriptions of this kind of words must combine a large amount of information concerning grammar and use in each entry, rather than a mere semantic description. Indeed, adverb usage is restricted by complex grammatical factors which are hard to include in dictionaries given that they are fundamentally semantic in their approach and are addressed to users who cannot always be expected to be well trained in linguistics. Consequently, a dictionary must decide how to explain the use of such words, while making every effort to do so without resorting to formalistic accounts that may not be sufficiently clear for the layperson.

The best way to represent adverbs in dictionaries is an issue for general lexicography, and it is particularly relevant to learners' lexicography. First, this is because learners' dictionaries are made for non-native speakers who lack a full command of a language's grammar. Such works are made as production aids, so they must provide the kind of information that will enable a non-proficient speaker of the language to use the entries they look up adequately. Second, there are often differences in the way equivalent adverbs in different languages are used, so a good dictionary must help learners avoid semantic calques. 
We can illustrate the kind of problems involved in lexicographically dealing with adverbs by examining a few data on the use of adverbs in English and Spanish. Let's take, for instance, the English adverbs cleverly and intelligently (examples 1 and 2). Semantically, they are quite close; however, their grammar is different. The former can only be a verb phrase modifier, whereas the latter can also be a sentence modifier.

(1) a. He did not answer the question cleverly.

b. *Cleverly, he did not answer the question.

(2) a. He did not answer the question intelligently.

b. Intelligently, he did not answer the question.

In Spanish there is no such adverb as *listamente, deriving from the adjective listo ('clever'), and the Spanish equivalent for both of these adverbs is inteligentemente. This word can be used to modify a verb phrase (like cleverly, in 3a) or to modify a sentence (as an equivalent to intelligently, in $3 b$ ).

(3) a. No respondió a la pregunta inteligentemente.

'He did not answer the question cleverly / intelligently'

b. Inteligentemente, no respondió a la pregunta.

'Intelligently, he did not answer the question'

If we look at these data from an L2 learning perspective, we can see that the differences between these adverbs can account for errors both in English-speakers learning Spanish and in English-learning Spanish speakers. On the one hand, since inteligentemente and cleverly are equivalent in some contexts, a Spanish native speaker learning English might mistakenly believe that they are equivalent in all their uses. This would lead to producing an ungrammatical utterance like (1b) when wishing to express the contents of ( $3 b)$. On the other hand, a learner of Spanish with English as L1 might produce the non-existent *listamente from listo, given that English allows cleverly from clever.

The rules that make it possible to form an adverb from an adjectival base, along with the possibilities that an adverb can have various functions in a given language depend on factors which are highly complex and hard to foresee. Thus, there are frequent contrasts like the ones illustrated in examples (1) and (2) between adverbs which are semantically very close in a given language. For example, fast can only modify a verb phrase whereas quickly can also be a sentence modifier. Moreover, there are also frequent contrasts like the ones shown in cleverly / intelligently vs. *listamente / inteligentemente among equivalent adverbs from different languages. For example, in Spanish there are two equivalents for happily, each with different uses: alegremente can only modify a verb phrase, whereas felizmente can also modify a sentence. By contrast, the Spanish adverb which is opposite in meaning to both of these is tristemente, and it can take on both uses, just like sadly and unhappily, its two English equivalents.

A dictionary aiming to help a language learner become aware of this type of problem should provide adequate information about adverb usage. However, the explanations for adverbs in dictionaries are far from systematic and often not very informative. For example, the English adverbs mentioned in this section are treated very differently in some of the main English-language dictionaries, as shown in Table 1. Thus, there are adverbs like cleverly and intelligently that do not have their own entry in any dictionary, while others like happily and quickly have their own entry in some works, and in others they appear as sublemma of the entry for the adjectival base. In some cases, like sadly, there are descriptions of their uses as verb phrase modifiers and sentence adverbs in every dictionary, while in others, like happily, there are differences in the description of 
uses provided by each dictionary. Finally, there are adverbs for which no dictionary offers any explanation as to how to use them in a sentence, e.g. quickly, despite the fact that the dictionary gives them their own entries.

\section{INSERT Table 1. Adverbs in English dictionaries.}

The inconsistencies in the ways these adverbs are dealt with, as we have seen, have to do with both the macrostructure of a dictionary and the microstructures of its entries. A lack of clear macrostructural criteria can be observed when it comes to deciding whether a given adverb even appears in the dictionary with its own entry or whether its existence is simply broached in the list of words deriving from the adjectival base. It must be noted that in such cases the dictionary offers no information at all about the adverb, presumably assuming that the user will be able to infer its meaning from the adjective's. However, there is a disregard for the fact that the non-proficient user cannot work out how to use an adverb on the sole basis of a cross-reference. How can one, for instance, discover the difference in use between cleverly and intelligently, which in every dictionary are included solely in the lists of words derived from the adjective entry?

As for the microstructure of the entries, there are two major shortcomings. First, they are not systematic enough when it comes to distinguishing the various uses that an adverb might have, i.e. there is no consistency in different meanings of a given entry. For example, in COBUILD6, happily is shown solely as a verb modifier, while unhappily is shown only as a sentence modifier, although both adverbs allow both uses, as confirmed in other dictionaries under study. Likewise, none of the dictionaries deal with the sentence uses of quickly.

Second, there does not seem to be a consensus for the best way to define an adverb for those cases where a definition is offered. For example, OALD7 and MEDAL2 define fast as a synonym of quickly, although these adverbs are not equivalent in every use. OALD7 further defines quickly as fast, thus creating a circular definition. Other dictionaries, such as AHD4 or COBUILD6 tend not to define adverbs. COBUILD6 usually includes an example along with a grammatical code (Adv-ed; Adv after v; Adv with v; Adv with $c l$, etc.), although some of the abbreviations used are not clear. Finally, in some cases dictionaries include definitions other than synonyms. In such cases, however, there once again does not seem to be consensus as to the best way to define adverbs. So, sometimes there is a glossed semantic equivalent (definition proper), whereas in other examples there is a metalinguistic explanation of the word's use. We could compare, for example, the first two meanings provided for happily in MEDAL2, the first one a metalinguistic explanation of its use and the second one a definition proper:

\section{happily}

1. Used when you are pleased about something. Happily, she wasn't injured in the crash.

2. In a happy way. 'Yes,' he said, smiling happily. He and his wife are happily settled in their new home.

It must be pointed out, moreover, that the definitions with the formula used in the second meaning for happily - 'in an Adj way' - are traditional in lexicography. For example, ODE3 uses the same type of definition for happily, sadly and unhappily. However, such definitions are not really informative, because they can already easily be inferred from the word's morphology. Furthermore, they refer to entries of adjectives 
which are quite polysemous but do not properly clarify whether the adverb can take on all of its adjectival base's possible meanings.

To sum up, there is evidence that dictionaries are inconsistent in the way they deal with adverbs. The fact that the inconsistencies are present not only from one dictionary to the next but even within the same dictionary suggests the need to rethink the criteria that are to be followed in dictionaries' accounts of adverbs. In the following sections of this paper there is a detailed discussion of the main issues on which the lexicographer must make decisions when confronted with dealing with adverbs, with particular focus on Spanish - mente adverbs. In short, lexicographers must decide which adverbs are to be included in the dictionary and how these adverbs relate to the adjectival bases they derive from (Section 3). They must also decide how adverbs are defined and how grammatical and discourse properties of adverbs are presented in lexicographical articles (Section 4). In all these aspects, specific decisions which were taken in the case of DAELE are presented and discussed.

\section{Macrostructural decisions: lemmatization and the relationship between adverbs and adjectival bases}

The first question related to the lexicographical treatment of -mente adverbs is to decide which adverbs to include in the dictionary. Lemmatization problems of -mente adverbs are a consequence of the morphological nature of these lexical units. They are morphologically derived words ${ }^{3}$ formed from adjectives by means of a highly regular process. In Spanish lexicographical tradition, derivatives are usually included as separate entries, independent from the base they derive from. For example, cuestionable ('questionable') has its own entry in the dictionary, independent from cuestionar ('to question'), although the derivation of adjectives from verbs with the suffix -ble is a very regular morphological process, and the meaning of the derived adjective is easily inferred.

There are two main exceptions to this treatment of derivatives in Spanish dictionaries (Beniers 1990, Bernal 2003): the so-called 'evaluative derivation', that is, diminutives and augmentatives (García Pérez and de Hoyos 1997), and-mente adverbs. The lexicographical treatment of diminutives and augmentatives is quite homogenous in most dictionaries: evaluative derivatives have separate entries only if they have developed a lexicalized meaning (pasillo 'corridor', from paso 'way'; bocadillo 'sandwich', from bocado 'mouthful'; sombrilla 'parasol', from sombra 'shade') or if there is some irregularity in their morphological process (bobalicón, 'simpleton', from bobo 'stupid, silly'; bestezuela, 'small animal', from bestia 'beast'). There are two reasons for this treatment. One is that the meaning of augmentatives and diminutives is quite transparent (large or small size, sometimes with an added positive or negative connotation). The other reason is that this morphological process is quite productive and overloading a dictionary with a large number of uninformative entries is deemed unnecessary.

Contrary to this lexicographically homogeneous treatment, three different solutions to the lemmatization of -mente adverbs have been proposed in Spanish lexicography (Azpiazu 1998-1999, Perdiguero 2006; cf. also Corbin 1982 for French and De Cesare 2003 for Italian). There are theoretical arguments for and against each solution. According to Torner (2010), these solutions can be placed on a scale between two extreme positions, the maximalist criterion of lemmatizing all existing -mente adverbs and the minimalistic criterion of including very few lexicalized forms. 
DAELE has gone for the most inclusive option, i.e. all possible -mente adverbs deriving from adjectives included in the dictionary are lemmatized if documented in textual corpora. ${ }^{4}$ Taking into account that DAELE is a dictionary fundamentally conceived as a codifying tool, we consider that the mere fact of indicating that an adverbial form exists constitutes useful information for language learners.

Closely related to the lemmatization problem is the question of how to reflect the semantic relationship between an adverb and the adjective from which it derives. Indeed, as morphologically derived units, adverbs inherit their nuclear meaning from the adjectival base, except for some cases of lexicalization. Nevertheless, as Torner (2005a, 2007) shows, the semantic relationship between adjectives and adverbs yields a complex puzzle. Adjectives often have numerous meanings in dictionaries, but it is only possible to form -mente adverbs from some of those meanings. For example, estoicamente (derived from estoico 'stoical') can refer to mental strength only and not to Greek philosophy. Further, each meaning of an adverb is related to a particular meaning of the adjectival base. For example, felizmente may mean 'happily' (from feliz 'happy' applied to persons) in (4) or 'fortunately' (from feliz 'fortunate' applied to events) in (5).

(4) Están felizmente casados. 'They are happily married'

(5) Felizmente, nos hemos reconciliado.

'Fortunately, we have made up'

Because of what has been said so far, and following Azpiazu (1998-1999) and Perdiguero (2006), DAELE indicates the relationship between the adverbial meaning and the meaning of the adjectival base from which it is derived in both the adverb and adjective entries.

What follows, in Section 3.1, is an in-depth examination of the morphological aspects of the process of adverb formation with the suffix - mente in Spanish, which will enable us to argue for the criteria used in DAELE in Section 3.2.

\subsection{The linguistic problem: the morphological process of-mente adverb derivation}

The formation of -mente adverbs is highly productive in Spanish. The -mente ending is a derivational suffix which takes as its base an adjective in the feminine singular form. This process is parallel to other adverb formation processes in Romance languages (for example, -ment in Catalan and French), and is very similar to adverb derivation processes in other languages (for example, $-l y$ in English). Typically, the process operates on qualifying adjectives and yields manner adverbs as a result. For example, the adjective lento 'slow' forms the adverb lentamente, the meaning of which is 'in a slow manner'. Manner is the etymological meaning as well as the first historically documented one (Karlsson 1981).

Nevertheless, several studies on adverb morphology have noted that this process is far from being absolutely regular. In the first place, there are the many gaps; i.e. a large number of adjectives do not produce - mente adverbs. Thus, the adverbs *azulmente, *terceramente o *francésmente, potentially derived respectively from the existing adjectives azul 'blue', tercero 'third' and francés 'French', do not exist. In the second place, many Spanish -mente adverbs do not have the typical manner meaning or they do not admit the paraphrase de un modo $X$ 'in an $\mathrm{X}$ way' characteristic of these adverbs made up from Adj+mente. For example, territorialmente 'territorially' doesn't mean 'in a territorial way' but 'with respect to territory'. Similarly, técnicamente 'technically' 
has two different meanings: 'by means of technique or technology' and 'from a technical point of view'.

Lexical gaps in Spanish -mente adverb formation pose a problem with no straightforward solution (González García 1997). Traditional studies in morphology have tried to account for these gaps by means of long lists of adjectives which cannot form -mente adverbs (Egea 1979, Varela Ortega 1990 and Kovacci 1999, among others). According to these studies, adverbs cannot be formed from the following groups.

- An overwhelming majority of numerals (except forms like primeramente 'firstly' or doblemente 'doubly');

- Relational adjectives which indicate origin (francés 'French', inglés 'English') or position (presidencial 'presidential');

- Qualifying adjectives which indicate physical or material qualities (azul 'blue', joven 'young', canoso 'grey-haired'), although some of them may form adverbs when they do not designate a physical quality (trabajar duramente 'to work hard', castigar duramente 'to punish harshly');

- Some adjectives ending in -ble, $-d o r$ and -nte if they are not negative (*evitablemente as opposed to inevitablemente 'inevitably'; but agradablemente 'pleasantly', amablemente 'kindly').

However, this approach has two main drawbacks. First, these lists are not comprehensive. For instance, the above list of adjectives which cannot form -mente adverbs may be extended to include thematic (relational) adjectives, i.e. adjectives which fill an argument position of the noun, as constitucional 'constitutional' in reforma constitucional 'Constitutional reform' (i.e. 'reform of the Constitution') (Bosque 1993, Bosque and Picallo 1996, Demonte 1999). Second, it lacks explanatory power. It does not explain why an adjective can or cannot form a -mente adverb, in other words, which features are shared by all the adjectives which allow adverb derivation.

The puzzle of the gaps in -mente adverb productivity is closely related to a second descriptive problem: its occasional semantic unpredictability. As Azpiazu (1998-1999) notes, it is often the case that an adverb may only be formed from an adjectival base meaning that is not its nuclear meaning, as in claramente 'clearly' (from claro 'light, pale' applied to colours, and only metaphorically applied to cognitive perception), prácticamente 'nearly' (from práctico 'practical', and only occasionally 'mere'), seguramente 'probably' (from seguro 'sure', which may be used as a pragmatic equivalent to 'probable'). On other occasions, an adjective may form an adverb capable of carrying each of the corresponding meanings, as is the case for religioso 'religious':

(6) Vivir religiosamente

'To live religiously' ('according to the principles and dogmas of a religion')

(7) Pago los impuestos religiosamente.

'I pay my taxes religiously' ('I never fail to pay my taxes')

Torner (2005a, 2007) proposes an alternative way to explain morphological productivity gaps and occasional semantic unpredictability in adverb formation processes. Briefly stated, adjectives which cannot form -mente adverbs do not form a 
homogeneous group, so, considered as a whole, there is not just one reason why they do not form adverbs. Each adverb subclass derives from a different adjective subclass, and thus the adverb formation process has different restrictions, depending on the adjective subclass from which the adverb derives.

All this means that being able to make a -mente adverb depends on the nature of the adjective. An adjective will yield adverbs of a certain subclass provided it has semantic and grammatical features shared by the adjectives that produce adverbs of that subclass. We must also take into account the fact that many polysemous adjectives include meanings that make them behave as if they belong to different subclasses. For example, familiar is relational in (8) and qualifying in (9). ${ }^{5}$

(8) Los cuidados maternales

'Maternal care'

(9) Una actitud muy maternal

'A very mother-like attitude'

The meaning illustrated in (9) allows the existence of the adverb maternalmente, but it is not possible to make an adverb from the meaning illustrated in example (8). Thus, a deeper analysis of adjective semantics is needed to better understand adverb formation in Spanish, because the possibility of forming an adverb from a given group is not a property that depends on the adjective's meanings as a whole, but on each one of its individual meanings.

From a lexicographical perspective, two of the main aspects stated in the previous description must be taken into account. First, rules governing the -mente adverb formation process seem to be opaque in most cases. Therefore, it must not be assumed that learners are able to predict which adjectives are able to form adverbs nor which meanings and uses the adverbs might have. Indeed, several studies point out that learners often have problems producing derived adverbs (cf. Schmitt \& Boyd Zimmerman 2002, among others). Thus, it seems reasonable to include all possible Spanish - mente adverbs in the dictionary, especially in a learners' dictionary like DAELE, which has been conceived as a codification tool. Second, it has also been demonstrated that adverbs inherit the meaning of only one of the possible meanings of the adjective base. Understanding an adverb, therefore, implies knowing which meaning of the adjective it is derived from. In order to facilitate the link between meanings, DAELE proposes to hyperlink each adverb sense with its corresponding meaning in the adjective entry.

\subsection{The lexicographical solution: macrostructural decisions in DAELE}

A deeper knowledge of the semantic aspects related to the morphological-mente adverb formation process has significant implications for the criteria used to decide on the macrostructure of the dictionary. This section presents the macrostructural features used in DAELE. They affect both the selection of adverbs lemmatized and the way to link them to the adjective bases they derive from.

First of all, the criteria for the selection of adverbs to be entered into the dictionary must be established. Spanish lexicographical praxis offers a scale of solutions for the lemmatization of -mente adverbs. The dictionary may include entries only for adverbs that have developed a lexicalized meaning different from that of the adjectival base seguramente 'probably' (< seguro 'sure') — or for adverbs which derive from metaphorical meanings of adjectives - claramente 'clearly' ( $<$ claro 'light, pale', and 'clear' by means of a metaphor). In this alternative, -mente adverbs have an analogous 
treatment to that of evaluative derivation. This minimal treatment is applied in Clave, which lemmatizes only 39 -mente adverbs.

A less rigid version of this treatment also exists. It consists of expanding the group of adverbs entered in the dictionary with all the forms which are not used to describe manner or which cannot be defined by means of the formula 'de un modo + Adj' ('in an Adj manner'): for example, sinceramente ('frankly') as a speaker-oriented adverb, or ciertamente ('indeed') as a conjunct. It is difficult to put this option into practice coherently, however, due to the complexity of -mente adverbs. This treatment is used rather inconsistently in the dictionaries that have adopted it. It is the treatment that has been used, although not explicitly, in DUEAE and in Salamanca (which include nearly 250 - mente adverbs).

The most inclusive option is to lemmatize all possible -mente adverbs. It is the solution which Azpiazu (1998-1999) argues for ${ }^{6}$. It is also the option used in DEA, as described in its prologue (p. XVI): ${ }^{7}$

En este diccionario se incluyen todos los adverbios [en -mente] - tanto si su significado está ya en el adjetivo primitivo, como si ha desarrollado otros- cuya circulación real ha quedado comprobada.

One argument against this maximal option is that a large number of not very informative entries increases the size of the dictionary unnecessarily. However, there are strong arguments for it. Indeed, numerous Spanish adjectives do not form adverbs. For example, as discussed above, it is not possible to derive adverbs from some relational adjectives (francés 'French' > *francésmente, ballenero 'whaling' > *balleneramente), from colour adjectives (amarillo 'yellow' $>$ *amarillamente) or from most derived adjectives with the suffixes -ble, -dor or -nte if they are not negative (evitable 'avoidable' > *evitablemente, but inevitable 'inevitable' > inevitablemente). Moreover, there are differences among languages in adverb-formation processes: adjective semantics is not always equivalent in different languages, and semantic and morphological restrictions to adverb formation from adjectives may differ across languages. For example, there is not a Spanish equivalent to the French adverb autrement, derived from autre 'other', even though the equivalent adjective otro 'other' does exist. Similarly, the English adverb roughly has two meanings, 'in a rough way' and 'approximately', but its Spanish equivalents toscamente and rudamente have the former meaning only. Therefore, the non-inclusion of an adverb in the dictionary constitutes information for users in and of itself: it tells its readers that a-mente adverb does not exist in Spanish.

Although not always explicitly, these various options are based on different conceptions of both how morphology should be treated in dictionaries and what kind of knowledge speakers need to predict that an adverb can be formed from a given adjective. Thus, the minimal option (i.e. minimally inclusive, whereby only lexicalized forms are included) assumes that the dictionary user has sufficient linguistic knowledge to predict all the cases of possible adverb formation. On the other hand, the maximal option assumes that the user needs explicit information about actual solutions in language because of the complexity of the process.

DAELE goes for the maximally inclusive option; that is, there is an entry for all adverbs which are documented in the reference corpora. This decision is based on three different criteria. First, DAELE is a learners' dictionary, written for users with a lower language competence than that of native speakers. Therefore, it must not be assumed that their language competence allows them to predict all possible cases of -mente adverb formation correctly. In fact, several studies have highlighted the difficulty that L2 learners have in the acquisition of derivatives. Schmitt (1998) and Schmitt \& Boyd 
Zimmerman (2002) observe that learners of English have certain problems in their productive knowledge of derivatives. The studies determine that these problems are especially frequent for adjective and adverb forms. The results of these studies suggest that it may not be assumed that the knowledge of one word in a family entails productive knowledge of other words in that family. This is highly relevant to the upper-level L2 students at whom DAELE is targeted. As Jiang (2000) observes, the acquisition of syntactic and morphological features of words is the last stage of vocabulary acquisition. Many learners do not manage to integrate use-related information in their lexicon until their vocabulary, or part of it, has fossilized. One must also take into account that, in the case of an electronic dictionary like DAELE, space is not a reason for not including derivates, as there are no restrictions in this sense (ten Hacken 2006).

Second, while current scholarly knowledge of the -mente adverb formation process has provided us with an understanding of the general mechanisms which control it (mechanisms of semantic and argument selection according to their adjectival roots), further study looking into specific restrictions operating in all possible Spanish adverbs must nevertheless be undertaken. As ten Hacken (2006) and Aronoff \& Cho (2001) argue, while word formation processes are rule-based, language-specific constraints on the application of these rules are quite intricate.

Third, some grammatically possible forms may not be documented in actual use of a language; that is, a language may not develop all of the adverbs it could. This means that the minimal option demands better linguistic knowledge from the users. They need to have not only a procedural and unconscious knowledge of the rules which govern the formation of -mente adverbs in Spanish but also an unconscious knowledge of which potential forms are actually used in Spanish. Neither of these two types of knowledge has necessarily been acquired by the non-native speakers that form DAELE's target readership.

In summary, then, DAELE includes all forms whose use is documented in the linguistic corpora used to compile it. Nevertheless, it should be noted that DAELE is a learners' dictionary with a core vocabulary comprising high-frequency words. That is why its entries are a selection of Spanish vocabulary chosen according to pedagogical criteria, such that only high frequency adverbs are included in the dictionary. The correspondence between adjectives and -mente adverbs included must be controlled so as to avoid inconsistencies. All possible and corpora-documented adverbs derived from all lemmatized adjectives must be included in the dictionary, and vice versa.

The second decision concerns how to relate adverbs to the adjectival bases they derive from. As seen above, there is a close relationship between adjective semantics and -mente adverb formation possibilities: only adjectives which have certain semantic features are able to produce adverbs of a specific subclass. Adjectives are typically polysemous words, especially the ones which constitute the core lexicon of a language. These are the adjectives included in DAELE. DAELE's authors advocate that, in a learners' dictionary, the relationship between an adverb and the adjective meaning it derives from must be made explicit to help the user fully understand the adverbial meaning.

In a radical approach, Azpiazu (1998-1999) argues that adverbs must not be included as independent entries in dictionaries but as subentries in the corresponding adjective entry, as illustrated in the following example (partially reproduced from Azpiazu 19981999: 16):

\section{religioso, a}

1. adj. Perteneciente o relativo a la religión o a los que la profesan. 
1a. -mente: adv. m. Con religión.

[...] 4. Fiel y exacto en el cumplimiento del deber.

$\square$ 4.a. -mente: adv. m. Con puntualidad y exactitud.

This norm had been applied in some English learners' dictionaries, as shown in Section 2. However, it is lexicographically inadequate for DAELE for three reasons. First of all, because it breaks with well-established Spanish lexicographical tradition, in which derived words are not usually included as subentries (Beniers 1990). As Kilgarriff (1997: 100) observes, 'investors will not lightly adopt policies which make their product radically different to the one known to sell'. Second, because sometimes it does not adhere to the alphabetical order: in adjectives with two inflectional forms, the adverb alphabetically precedes the adjective (it is formed from the feminine form, ending in $-a$ ), and sometimes it is separated from the adjective by several words, not always in the same lexical family. For instance, altamente ('highly') alphabetically precedes alto ('high') in a general Spanish dictionary and there are more than 60 words between the two entries. Even though some of them might not be included in a learners' dictionary, about half of them are ${ }^{8}$ making them appear quite far from one another in the list of entries. Since in the case of an electronic dictionary there are different ways of accessing the lexicographical entries and avoiding this problem (Nielsen 2002, de Schryver 2003, Gelpí 2003, Fernández-Pampillón \& Matesanz 2006, among others), it may be assumed that users might do their search from the alphabetical list of entries. Thirdly, as Procter (1987) argues in the Dictionary of Contemporary English, derivatives should be headwords in a learners' dictionary because users cannot be expected to analyze them morphologically. It has been argued, on pedagogical grounds, that the use of sublemmata is not good practice in the case of learner's dictionaries and that this practice should be kept to a minimum (Steyn 2004).

For these reasons, adverbs in DAELE have separate entries which are independent from their base adjectives, albeit linked to them. Moreover, the use of hyperlinks to relate derivatives to their bases highlights the didactic nature of learners' dictionaries. This has been argued to be an important asset in the acquisition of vocabulary because it contributes to a better organization of lexicon in the learners' mind (Ten Hacken 2006). Psycholinguistic studies show that a better structured lexicon facilitates both lexical comprehension and production (Casiddu 1996). As has been noticed in classical studies, learners' dictionaries 'should be seen first of all as a language-learning resource, its compilers as much in the business of language teaching as of lexicography' (Rundell 1988: 134).

The mechanism used to link adverb and adjective entries should be user-friendly. In traditional paper format dictionaries, the solution is not easy, since cross-references entail a new search - which users usually do not undertake if they have already solved the doubt that led them to consult the dictionary in the first place. As DAELE is a dictionary in electronic format, it allows hypertextual links. Thus, in DAELE, crossreferences take the form of a hyperlink. The user does not need to carry out a new search. Reciprocal and easy-to-use hyperlinks between meanings of adjectival bases and adverbs are established. In the adjective entry, there is an indication that a -mente adverb derivation is possible from a specific meaning. In the adverb entry, a link will take the user to the corresponding meaning of the adjectival base. The adverb > adjective link is fundamentally conceived as a comprehension tool, whereas the adjective $>$ adverb link is a guide for production, as it helps the user pick up new derived words. 


\section{Microstructural decisions: including grammatical and use information in adverb definitions}

The second question concerning the lexicographical treatment of -mente adverbs is how both the meaning and use of - mente adverbs can best be represented in dictionary definitions. This question is closely related to the problem of representing grammatical information in the adverbial entries of the dictionary. It must, therefore, be decided exactly how much grammatical and discursive data concerning - mente adverbs, if any, should be included in dictionary entries. Recent research in adverbial syntax has provided very refined characterizations of the grammatical behaviour of adverbs, while research in discourse analysis has provided a great amount of data about its use. Because of the very fine-grained knowledge of adverbial grammar and use coming from linguistic studies, lexicographers must decide whether and how to include it in the dictionary. ${ }^{9}$

Three questions must be considered. First, is it necessary to include such information in dictionary entries? It may be argued that a dictionary is not a grammar, so its function is not to repeat information that may be found in other sources more completely and systematically. But it is also true that a considerable amount of grammatical and pragmatic information is associated with lexical items and that a dictionary conceived as a tool for production must include some of this information because it is needed to produce correct sentences.

Second, which linguistic information should be included in lexicographical entries? Adverbial grammar constitutes a complex puzzle, of which theoretical linguistics has analysed many syntactic aspects, such as word order, negation scope effects, mutual incompatibility with sentence modalities, aspect and lexical selection restrictions, argument orientation and passive sensitivity. Furthermore, studies in discourse analysis have provided a detailed description of many aspects related to adverb pragmatics, such as incidence on speech act level, evidentiality and connection to inferred meaning. Of course, not all of this information needs to be included in dictionaries.

Third, how is the grammatical and usage information to be presented in lexicographical entries? Two main problems arise at this point. The first one derives from the necessary fragmentation of information about the same grammatical category that alphabetical order imposes. The second one is related to the explicitness of the information provided. Linguistic information on grammar and use may be represented either explicitly, for instance by means of marks, or implicitly, by means of examples. Specialized literature has not reached a consensus in this sense, as it is stated by Bogaards (2001).

Section 4.1 offers a brief presentation of the main aspects of the grammar and use of adverbs, which are the phenomena that must be represented in lexicographical entries. Section 4.2 presents the proposed solution to this matter used in DAELE.

\subsection{The linguistic problem: adverbial grammar and use}

Our current knowledge about adverbs has been enormously enriched thanks to advances in linguistic investigation over the last half century. Traditional grammar claimed that adverbs were almost completely limited to the function of modifying verbs - as the term ad verbum has engraved in its etymon. However, modern linguists (e.g. Greenbaum 1969 or Jackendoff 1972) very soon realized that adverbs have numerous functions. Many specialized studies over the last four decades have examined the variety of non-manner uses of adverbs in different languages. For example, in (10)-(12) 
the adverbs act as sentence modifiers: they do not modify the verbal action but rather some other feature of the sentence or discourse.

(10) Sinceramente, no te entiendo. 'Honestly, I do not understand you'

(11) Desgraciadamente, no llegamos a tiempo. 'Sadly, we didn't arrive in time'

(12) Inteligentemente, el entrenador dejó descansar a los jugadores más importantes. 'Intelligently, the coach allowed the most important players to rest'

The adverb is speaker-oriented in (10), that is, it indicates the speaker's attitude when speaking; evaluative in (11), that is, it indicates a speaker's evaluation of the fact expressed; and agent-oriented in (12), that is, it evaluates the fact that the agent acts as expressed. The specialized literature on adverbs has been dedicated fundamentally to distinguishing between these uses, called disjuncts, and the uses in which the adverb acts as a verb modifier, called adjuncts (Quirk et al. 1985), illustrated in the following examples:

(13) Juan habló sinceramente cuando dijo que estaba arrepentido.

'Juan spoke sincerely when he said that he was sorry'

(14) El asunto terminó desgraciadamente.

'The matter ended in misfortune'

(15) No contestó inteligentemente.

'He did not answer intelligently'

Studies on adverbs have provided much grammatical data related to these differences in adverbial usage. Discussion on this topic is extensive because these differences affect central aspects of syntactic theory on sentence structure (cf. Haumann 2007 for an updated revision). ${ }^{10}$ As a result, we now have much more accurate descriptions of the grammar of adverbs. The details of these descriptions are not the focus of our interest here; however, it is important to point out that there is a correlation between the functions - which roughly correspond to dictionary meanings - and the grammatical properties that adverbs have in their uses. Just to mention two of the aspects studied in greater detail, it has been noted that the opposition between verb phrase modifier and sentence modifier affects the scope of negative operators and word order. Adjuncts are within the scope of negative operators, whereas disjuncts are not.

(16) a. Adjunct:

No contestó inteligentemente (sino de forma estúpida / *sino que se quedó callado). 'He did not answer intelligently (but stupidly / *he remained silent instead)'

b. Disjunct:

Inteligentemente, no contestó (*sino de forma estúpida / sino que se quedó callado). 'Intelligently, he did not answer (*but stupidly / he remained silent instead)'

In addition, adjuncts occupy lower syntactic positions within the verb phrase whereas disjuncts occupy higher syntactic positions. They are generally parenthetical, separated from the sentence by pauses, and are allowed a greater variety of positions in the sentence: ${ }^{11}$ 
(17) (a) *Inteligentemente el pintor ha combinado muchos colores.

(b) *El pintor inteligentemente ha combinado muchos colores.

(c) El pintor ha combinado inteligentemente muchos colores.

(d) El pintor ha combinado muchos colores inteligentemente.

'The painter has combined many colors intelligently'

(18) (a) Inteligentemente, el pintor ha combinado muchos colores.

(b) El pintor, inteligentemente, ha combinado muchos colores.

(c) El pintor ha combinado, inteligentemente, muchos colores.

(d) El pintor ha combinado muchos colores, inteligentemente.

'Intelligently, the painter has combined many colors'

Furthermore, studies in discourse analysis have shown that some of the disjunct uses have a function that must be explained from a pragmatic point of view. For instance, sinceramente in (10) refers to the speaker's attitude, so it affects the speech act level. Other adverbs, such as resumidamente 'in sum' or literalmente 'literally', also act at speech act level, given that they evaluate the way in which linguistic code is used. Moreover, in (19) the adverb is an evidential, and the interpretation appeals to contextually inferred content: something must be assessed to be evident if both speaker and addressee share the information needed to conclude this:

(19) Evidentemente, llega tarde.

'Obviously, he is late'

The pragmatic properties of adverbs are beyond the scope of this work. Nevertheless, it is worth highlighting that description of grammatical and pragmatic properties of adverbs entails managing a lot of specialized linguistic information. The lexicographer must decide whether to show this kind of information in the description provided for the whole range of adverbs included in the dictionary. On this point, there are three aspects that must be taken into account from a lexicographical point of view. First, -mente adverbs are usually multifunctional, that is, a lexical unit may be used as adjective modifier, as a verb phrase modifier and as a sentence modifier. They may even be used in more than one verb phrase or sentence uses if the adjectival base is polysemous. In several cases, there are regular correlations between subclasses. For instance, adverbs that may be used as agent-oriented adjuncts may also be used as agent-oriented disjuncts, as in (16)-(18), and adjuncts derived from relational adjectives may usually be used as sentence domain adverbs, as shown in (20) and (21).

(20) La película está bien resuelta técnicamente.

'The film is well produced from a technical point of view'

(21) Técnicamente, la película es magistral.

'Technically, the film is brilliant'

In other cases, there are no such correlations or they are less regular. This is why all functions in which an adverb can be used are explicitly defined in DAELE, as De Cesare (2003) proposes for Italian dictionaries.

Second, conclusions from specialized literature bring to light the fact that the differences in adverb use are not fundamentally semantic. That is, the contrast in (16), (17)-(18) and (20)-(21) is not due to the fact that the adverb has different meanings but to the fact that it modifies a different sentence or discourse component: the verb phrase in adjunct uses as opposed to the sentence as a whole or a certain aspect of the statement in disjunct uses. ${ }^{12}$

That is to say, the core meaning of an adverb remains constant in its different functions, since interpretation differences across functions are due to the fact that the adverb modifies different linguistic elements in each case. As a consequence, for a 
dictionary to account for the functions in which an adverb may be used, it is not enough to gloss meaning; rather, reference must be made to the linguistic element modified by the adverb. That involves using, in one way or another, linguistic concepts (such as speech-act, speaker, agent or proposition) in lexicographical descriptions, as Perdiguero (2006) proposes. For example, to explain the uses of inteligentemente illustrated in (16) the dictionary needs to specify who or what the intelligence is attributed to.

Third, differences between adverbial functions (that is, between different uses of both predicate and sentence modification) have important grammatical correlations that we have not discussed here. The most salient of them is sentence word order. Since learners' dictionaries are production-oriented, they must include this information. The option that has been taken in DAELE is that a part of this grammatical information is explicit in definitions, whereas most of it is implicitly given in its examples. Section 4.2 discusses the solutions adopted in DAELE.

\subsection{The lexicographical solution: the microstructure of-mente adverb articles}

From the semantic and grammatical description given above, we conclude that the lexicographical description of -mente adverbs in a learners' dictionary must follow criteria listed in a) to d), below.

a) They must show explicitly every use an adverb may have (i.e. all of its functions).

b) They must define these uses with explanatory glosses; for some functions (especially, in disjuncts), this involves referring somehow to linguistic concepts such as speech-act, speaker or agent.

c) They must show semantic invariants among uses in a user-friendly way.

d) They must indicate some relevant grammatical data, whether explicitly in the definition or implicitly by means of examples.

DAELE develops new ways of presenting information in learners' dictionaries so that the entries are clear for non-native users. This proposal for adverbs is based on a proposal currently being implemented for the treatment of verbs. As explained in previous works (López Ferrero and Torner 2008, Renau and Battaner 2010 and 2011, Battaner 2010 and Bernal and Renau 2010), in dictionary entries of verbs the various uses that an item can have are grouped together and ordered according to semantic criteria, as opposed to syntactic criteria. That in itself is an important innovation in Spanish lexicography, in which the headwords for verbs are divided into several senses grouped in function of morpho-syntactic characteristics, regardless of meaning, in such a way that two different constructions with the same meaning are presented separately. In contrast to this traditional approach, DAELE structures verb entries semantically and not syntactically. All uses of a verb sharing the core meaning are grouped together, regardless of their syntax (i.e. regardless of whether they are transitive, intransitive or pronominal constructions). All the uses grouped together are presented as sub-senses of the same meaning, which is defined with a 'generic semantic label' glossing the core meaning shared by all of them. Sub-senses are defined under this generic meaning; each definition corresponds to a different syntactic construction, as semantic glosses and examples make clear. This treatment may be illustrated by the article reproduced in Figure 1 (from López Ferrero and Torner 2008: 1527).

\section{INSERT Figure 1. Lexicographical article of a verb in DAELE}

This treatment of verb entries is similar to the one proposed by Lindstromberg (2001) for prepositions. As he argues, structuring entries with semantic criteria allows users to 
find the information they need quickly. Indeed, users may well begin by looking up the meaning of the word in the semantic headings, which facilitate a correct division of the entry. Once they have found the correct division, they can read it thoroughly to get further semantic or grammatical information.

According to this treatment, in the lexicographical entries for-mente adverbs, all uses sharing a given meaning are grouped together and presented as sub-senses of the same meaning. For example, the two uses of sinceramente in (22), which reproduces (10) and (13) above, are grouped together as a single meaning.

(22) (a) Sinceramente, no te entiendo.

'Honestly, I do not understand you'

(b) Juan habló sinceramente cuando dijo que estaba arrepentido.

'Juan spoke sincerely when he said that he was sorry'

Conversely, the following uses of religiosamente, corresponding to (6)-(7) above, are presented separately because the meaning of the adverb is different in each of them.

(23) (a) Vivir religiosamente

'To live religiously'

(b) Pagar las deudas religiosamente

'To pay debts religiously' ('never fail to pay debts')

The following uses of francamente are also considered different meanings. In (24) the adverb is related to the meaning of frankness, whereas in (25) it is used as an adjective modifier meaning 'very' and in (26) it has the meaning of 'no restriction'. All three meanings are inherited from different meanings of the adjectival base.

(24) (a) Le he respondido francamente.

'I have answered him frankly'

(b) Francamente, te estás equivocando.

'Frankly, you're wrong here'

(25) Su disertación fue francamente interesante.

'His dissertation was really interesting'

(26) Se durmió recostado francamente en el sillón.

'He fell asleep leaning comfortably against the armchair'

In dictionary entries of -mente adverbs, the meaning shared by all uses grouped together is concisely explained by a minimal semantic gloss. This gloss is not a definition but a guide for users as it informs them about the various meanings that an adverb can have. That is why it provides only minimum semantic information, and it does not give details of use, which is instead explained in the corresponding sub-senses. This means that the dictionary has two different levels of consultation. When used for decoding, the information given by the semantic gloss may be enough; in other cases, when the user is interested in details about use and construction, sub-senses may be consulted.

The semantic glosses of core meaning and definitions of sub-senses differ in the amount of information they provide, as well as in the sort of formulae used. Semantic glosses employ, if possible, the adjectival base. In such cases, the most commonly used gloss is the traditional adverb definition formula 'de un modo + Adj'. This enables an easy hyperlink to the adjectival base definition. It is not always possible to use this formula; that is why the core meaning is usually glossed by a noun in a prepositional phrase. ${ }^{13}$ Since the adverb in these cases also inherits the meaning of the adjectival base, it is linked to the entry. 
Sub-sense definitions provide a greater amount of information than semantic glosses. Adjunct uses are properly defined by means of a 'natural definition', as is common practice in many learners' dictionaries (Hanks 1987). Otherwise, for disjunct senses an improper definition (called 'functional definition' in Porto Dapena 2002: 282-283 and 'use definition' in Lara 2003: 113) is used, so the definition includes a formula such as 'se usa / se utiliza para' 'it is used to'. Even though disjunct uses may usually be defined by a natural definition similar to those used for adjunct senses, this kind of improper definition makes it easier to identify explicitly which linguistic element is modified by the adverb. These different types of formulae are illustrated in the following entry for sinceramente ('sincerely'):

sinceramente adv. DE MANERA SINCERA

1. Alguien dice o hace algo sinceramente cuando lo hace de manera sincera, sin mentir ni fingir.

Nos dijo sinceramente que estaba de acuerdo con nuestra propuesta.

Se arrepintió muy sinceramente de lo que había hecho.

2. El emisor usa sinceramente para indicar que expresa una opinión sincera, y que no finge ni miente.

Sinceramente, es mejor que lo olvides.

3. Antepuesto a una pregunta, se utiliza para pedir que la respuesta sea sincera.

Sinceramente, ¿a ti qué te parece el nuevo profesor? ${ }^{14}$

It should be noted that the beginning of the definitions of sub-senses 2 and 3 explicitly indicates the linguistic element modified by the adverb by referring to linguistic concepts in such a way that they are understandable to non-specialized readers. Some grammatical information, such as sentence word order, may be implicitly inferred from examples. It should also be noted that the definition of sub-sense 1 includes the formula of the general meaning, 'de una manera sincera', but adds some additional relevant information: a gloss of what manera sincera means ('sin mentir ni fingir' 'without lying or pretending'), implicit information of agent orientation in definition syntax ('alguien dice o hace' 'someone says or does'), indication of verbs with which it combines ('dice o hace'), etc.

\section{Conclusions}

Adverbs ending in -mente constitute a category which has a very heterogeneous treatment in Spanish dictionaries and which has received insufficient attention in metalexicographical studies. It is a lexical class of great linguistic complexity, so its lexicographical treatment is not straightforward. The difficulties in the lexicographical treatment of -mente adverbs can fundamentally be traced back to two distinctive features. First, they are used for a large number of functions. The differences between these functions are not semantic but fundamentally grammatical or discourse related, because the adverb usually has the same meaning in its various uses, although its contribution to sentence or discourse meaning differs. That poses a problem for lexicographers, as they must decide how to integrate grammatical, pragmatic and semantic descriptions in dictionary entries. Second, - mente adverbs are morphologically derived words formed from adjectival bases. The derivative process is a linguistic puzzle in many senses because there are frequent gaps in the -mente adverb formation process and because the process is not always predictable or semantically transparent. 
That poses a problem for the macrostructure of the dictionary, which should be considered in metalexicographical studies, and the solution to which may depend on the function of the dictionary and its potential users.

This paper has discussed the decisions taken at this regard in the DAELE, an electronic dictionary for advanced-level students of Spanish. From a macrostructural point of view, DAELE has taken a maximal option, including in the dictionary every adverb documented in the corpora which corresponds to the knowledge level of users to whom it is addressed. In order to show the relationship between adverbs and their adjective bases easily, the definition of the adverbs is made by using the adjective in it, thereby linking the corresponding adjectival and adverbial senses in the lexicographical entries by means of a hyperlink. In relation to microstructure, entries use a two-tier approach, providing information at two different levels. In one, semantics is the criterion used to structure the entry and senses are grouped under generic semantic glosses. In the other, a more detailed definition is offered, in which pragmatic and functional information is explicitly assessed and grammatical information is mainly offered implicitly through the examples.

\section{Notes}

1 This article is a contribution to the research project FFI2012-37654 - 'La representacion de la combinatoria lexica en los diccionarios de aprendizaje: nuevos metodos para nuevos diccionarios' (PI: Sergi Torner), funded by the Spanish Ministry of Economics. I thank Janet DeCesaris, Paz Battaner and two anonymous reviewers for comments to a previous version of the paper, and Adrianne Saltz and Patrick Zabalbeascoa for helping with proofreading.

${ }^{2}$ At present, a selection of 400 definitions of verbs is offered on www.iula.upf.edu/rec/daele/. For an updated overview of DAELE project, cf. Renau and Battaner (2011) and Mahecha and DeCesaris (2011).

${ }^{3}$ For the sake of simplicity, I assume that -mente adverbs are derivatives, according to Egea (1979), Karlsson (1981), Bosque (1989), Varela Ortega (1990) and Rodríguez Ramalle (1999, 2003), among others. Nevertheless, some other analyses have been proposed. In particular, some scholars (Bosque 1987, Zagona 1990, Kovacci 1999, among others) argue that -mente adverbs are compounds. For a detailed study of this question, see Torner (2005b).

${ }^{4}$ As stated in Renau and Battaner (2011) and Mahecha and DeCesaris (2011), DAELE is a corpusbased dictionary. We use three different corpora: the CREA (Corpus de Referencia del Español Actual) of the Real Academia Española, with 400 million words of all genres, both written and oral; the Corpus del Español compiled by Mark Davies, with 100 million words, also of all genres; and the Spanish Web Corpus, which has been loaded into the Sketch Engine, with 50 million words, mainly of press texts.

5 That is, in (8), the adjective means 'by a mother', while in (9) it means 'like a mother'. These two kinds of adjectives differ not only semantically but also from a syntactic point of view. For instance, the relational adjective in $(8)$ is not gradable $(*$ a very maternal care), unlike $(9)$, which is gradable.

${ }^{6}$ It is also the solution that De Cesare (2003) observes in modern dictionaries of Italian, which include all possible Italian - mente adverbs.

${ }^{7}$ My translation: 'This dictionary includes all - mente adverbs recorded from real usage — regardless of whether their meaning is already in the adjective root or whether they have developed new meanings.'

${ }^{8}$ For example: altanería, altanero, altar, altavoz, alterable, alteración, alterado, alterar, altercado, alteridad, alternadamente, alternado, alternador, alternancia, alternante, alternar, alternativa, alternativamente, alternativo, alteza, altibajo, altillo, altímetro, altiplano, altisonante, altitud, altivamente, altivez, altivo.

9 See Gutiérrez Cuadrado (1994) and Bargalló (2001) for a detailed discussion of the relationship between grammar and dictionaries.

${ }^{10}$ See also, among others, the works of Quirk et al. (1985), Alexiadou (1997), Cinque (1999), Ernst (2002) and Geuder (2002), and specifically for Spanish, Barrenechea (1979), Egea (1979), González García (1997), Kovacci (1999), Rodríguez Ramalle (1999, 2003) and Torner (2005a, 2007). 
11 There is no prosodic break in (17a) and (17b). Ungrammaticality judgments in these two examples refer to the impossibility of interpreting the adverb as an adjunct.

${ }^{12}$ Recent studies in adverbial semantics have not always agreed on what the adverb modifies exactly in the uses illustrated in (16b) and (18). See Geuder (2002) and Bonami and Godard (2007), among others, for a more detailed discussion.

${ }^{13}$ In general terms, the traditional formula definition with the adjectival base may be used in all mente adverbs except when they are polysemous, because this gloss does not allow us to distinguish different meanings, and in the following subclasses (whether they are monosemous or polysemous):

- Adjective modifiers, when the adverb has a degree-like value: realmente interesante 'really interesting', un enfoque fundamentalmente pedagógico 'a fundamentally pedagogical approach'.

- Adverbs derived from relational adjectives: técnicamente 'technically', estratégicamente 'strategically'.

- Focus adverbs: únicamente 'only'.

- Evaluative adverbs which indicate (un)favorable performing of an event: afortunadamente 'fortunately', felizmente 'luckily'.

- Connectives: primeramente 'first(ly)', finalmente 'finally'.

${ }^{14}$ Rough translation:

sincerely adv. IN A SINCERE WAY

1. Someone says or does something sincerely when they do it in a sincere way, without lying or pretending. He was sincere when saying [lit. 'he spoke sincerely'] that he agreed with our proposal. He sincerely regretted having done that.

2. The speaker uses sincerely to indicate he expresses a sincere opinion, that there is no deceit. Honestly, you'd better leave it out.

3. It is used before a question to ask the addressee to be sincere in his answer. To be honest, what do you think about the new teacher?

\section{References}

\section{A. Dictionaries}

Battaner, M. P. (dir.) 2002. Diccionario de uso del español de América y España. Barcelona: Spes Editorial. (DUEAE)

Gutiérrez Cuadrado, J. (dir.) 1996. Diccionario Salamanca de la Lengua Española. Madrid: Santillana. (Salamanca)

Maldonado, C. (dir.) 1996. CLAVE. Diccionario de uso del español actual. Madrid: SM. (Clave)

Procter, P. (ed.) 1978. Dictionary of Contemporary English. Harlow: Longman.

Rundell, M. (ed.) 2007. Macmillan English Dictionary for Advanced Learners (Second Edition.) Oxford: Macmillan Education. (MEDAL2)

Seco, M., Andrés, O. and Ramos, G. (eds.) 1999. Diccionario del español actual. Madrid: Aguilar. (DEA)

Sinclair, J. and Hanks, P. (eds.) 2008. Collins COBUILD Advanced Learner's English Dictionary. (Sixth Edition.) Boston: Heinle Cengage Learning. Glasgow: Harper Collins Publishers. (COBUILD6)

Stevenson, A. (ed.) 2010. Oxford Dictionary of English. (Third Edition.) Oxford: Oxford University Press. (ODE3)

The American Heritage Dictionary of the English Language. 2004. (Fourth Edition.) Boston: Houghton Mifflin Company. (AHD4)

Wehmeier, S. (ed.) 2005. Oxford Advanced Learner's Dictionary of Current English. (Seventh Edition.) Oxford: Oxford University Press. (OALD7). 


\section{B. Other literature}

Alexiadou, A. 1997. Adverb Placement. A Case Study in Antisymmetric Syntax. Amsterdam / Philadelphia: John Benjamins Publishing Company.

Aronoff, M. H. and Cho, S. 2001. 'The Semantics of -ship Suffixation'. Linguistic Inquiry 32: 167-173.

Azpiazu, S. 1998-1999. ‘¿Es factible un diccionario de adverbios en -mente?’. Revista de lexicografía 5: 7-32.

Bargalló, M. 2001. 'La información gramatical en los diccionarios especializados', in M. Bargalló et al. (eds.) Las lenguas de especialidad y su didáctica. Tarragona: Universitat Rovira i Virgili: 81-90.

Barrenechea, A. M. 1979. 'Operadores pragmáticos de actitud oracional: los adverbios en «-mente» y otros signos' in A. M. Barrenechea et al. (eds.), Estudios lingüísticos y dialectológicos. Temas hispánicos. Buenos Aires: Hachette: 39-59.

Battaner, P. 2010. 'El uso de etiquetas semánticas en los artículos lexicográficos de verbos en el DAELE'. Quaderns de filologia. Estudis lingüistics 15: 139-158.

Beniers, E. 1990. 'La derivación en la gramática y en el diccionairo'. Estudios de lingüistica aplicada 11: 102-115.

Bernal, E. 2003. 'Morfología y diccionario. Lagunas léxicas y lagunas lexicográficas en los sustantivos deverbales del sufijo -itzar del catalán' in C. Iacobini \& A. Thornton (eds.), Srcitti di morfologia in onore di Sergio Scalise in occasione del suo $60^{\circ}$ compleanno. Cesena: Caissa Italia: 13-28.

Bernal, E. and Renau, I. 2010. ‘ ¿Lo que necesitan es lo que encuentran? Reflexiones a propósito de la representación de los verbos en los diccionarios de aprendizaje de español' in A. Dykstra and T. Schoonheim (eds.), Proceedings of the XIV Euralex International Congress. Ljouwert: Fryske Akademy / Afuk: 484-496.

Bogaards, P. 2001. 'The Use of Grammatical Information in Learner's Dictionaries'. International Journal of Lexicography 14.2: 97-121.

Bonami, O. and Godard, D. 2007. 'Lexical Semantics and Pragmatics of Evaluative Adverbs' in C. Kennedy and L. Mc Nally (eds.), Adjectives and Adverbs in Semantics and Discourse. Oxford: Oxford University Press: 274-304.

Bosque, I. 1987. 'Constricciones morfológicas sobre la coordinación'. Lingüistica española actual 9: 83-100.

Bosque, I. 1989. Las categorías gramaticales. Madrid: Editorial Síntesis.

Bosque, I. 1993. 'Sobre las diferencias entre los adjetivos relacionales y los calificativos'. Revista Argentina de Lingüística 9: 9-48.

Bosque, I. and Picallo, C. 1996. 'Postnominal Adjectives in Spanish DPs'. Journal of Linguistics 32: 349-385.

Cassidu, M. B. 1996. 'Lessico mentale e produzione verbale: Modelli psicolinguistici e applicazioni didattiche'. Lingua e Nuova Didattica 2: 47-58 and 3: 23-36.

Cinque, G. 1999. Adverbs and Functional Heads. A Crosslinguistic Perspective. Oxford: Oxford University Press.

Corbin, D. 1982. 'Le monde étrange des dictionnaires (2): Sur le statut lexicographique des adverbes en -ment.' Lexique 1: 25-64.

De Cesare, A. M. 2003. 'Sur quelques aspects de la catégorie de l'adverbe. Focus sur six dictionnaires monolingues de l'italien'. International Journal of Lexicography 16.1: 3-17. 
Demonte, V. 1999. 'El adjetivo, clases y usos. La posición del adjetivo en el sintagma nominal' in I. Bosque and V. Demonte (eds.), Gramática descriptiva de la lengua española. Madrid: Espasa-Calpe: 129-215.

De Schryver, G. M. 2003. 'Lexicographers' Dreams in the Electronic-Dictionary Age'. International Journal of Lexicography 16.2: 143-199.

Egea, E. R. 1979. Los adverbios terminados en -mente en el español contemporáneo. Bogota: Publicaciones del Instituto Caro y Cuervo.

Ernst, T. B. 2002. The Syntax of Adjuncts. Cambridge: Cambridge University Press.

Fernández-Pampillón, A. and Matesanz, M. 2006. 'Los diccionarios electrónicos: hacia un nuevo concepto de diccionario'. Estudios de Lingüistica del Español 24. 18 February 2010. http://elies.rediris.es/elies24/pampillon.htm.

García Pérez, P. and de Hoyos, J. C. 1997. 'El problema de los diminutivos en el DRAE: revisión lexicográfica'. Interlingüística 6: 53-58.

Gelpí, C. 2003. 'El estado actual de la lexicografía: los nuevos diccionarios' in A. M. Medina Guerra (ed.), Lexicografía española. Barcelona: Ariel Lingüística: 307332.

Geuder, W. 2002. Oriented Adverbs. Issues in the Lexical Semantics of Event Adverbs. $\mathrm{PhD}$ Thesis, Universität Tübingen.

González García, L. 1997. El adverbio en español. A Coruña: Universidade da Coruña.

Greenbaum, S. 1969. Studies in English Adverbial Usage. London: Longman.

Gutiérrez Cuadrado, J. 1994. 'Gramática y diccionario' in Actas del Congreso de la lengua española: Sevilla, 1992. Madrid: Instituto Cervantes: 637-656.

Hanks, P. 1987. 'Definition and Explanation' in J. Sinclair (ed.), Looking Up: An Account of the COBUILD Project in Lexical Computing. London / Glasgow: Collins: 116-136.

Haumann, D. 2007. Adverb Licensing and Clause Structure in English. Amsterdam / Philadelphia: John Benjamins Publishing Company.

Jackendoff, R. S. 1972. Semantic Interpretation in Generative Grammar. Cambridge (Mass.): MIT Press.

Jiang, N. 2000. 'Lexical Representation and Development in a Second Language'. Applied Linguistics 21: 44-77.

Karlsson, K. E. 1981. Syntax and Affixation. The Evolution of MENTE in Latin and Romance. Tübingen: Max Niemeyer Verlag.

Kilgarriff, A. 1997. 'I Don't Believe in Word Senses'. Computers and the Humanities 31: 365-387.

Kovacci, O. 1999. 'El adverbio' in I. Bosque and V. Demonte (eds.), Gramática descriptiva de la lengua española. Madrid: Espasa Calpe: 705-786.

Lara, L. F. 2003. 'El sentido de la definición lexicográfica' in M. A. Martín Zorraquino and J. L. Aliaga Jiménez (eds.), La lexicografía hispánica ante el siglo XXI. Balance y perspectivas. Zaragoza: Gobierno de Aragón / Institución Fernando el Católico: 99-113.

Lindstromberg, L. 2001. 'Prepositions Entries in UK Monolingual Learners' Dictionaries: Problems and Possible Solutions'. Applied Linguistics 22.1: 79-103.

López Ferrero, C. and Torner, S. 2008. 'Verbos que traban discurso: implicaciones lexicográficas para el DAELE' in E. Bernal and J. DeCesaris (eds.), Proceedings of the XIII EURALEX International Congress (Barcelona, 15-19 July 2008). Barcelona: Institut Universitari de Lingüística Aplicada (Universitat Pompeu Fabra) - Documenta Universitaria: 1519-1528. 
Mahecha, V. and DeCesaris, J. 2011. 'Representing Nouns in the Diccionario de aprendizaje del español como lengua extranjera (DAELE)', in I. Kosem and K. Kosem (eds.), Electronic lexicography in the 21st century: new applications for new users. Proceedings of eLex 2011. Trojina: Institue for Applied Slovene Studies: 180-186.

Martínez Marín, J. 2006. 'Los adverbios en -mente y los diccionarios modernos en español: perspectiva pragmático-discursiva' in M. Casado Velarde, R. González Ruíz and V. Romero Gualda (eds.), Análisis del discurso: lengua, cultura, valores: Actas del I Congreso Internacional. Madrid: Arco-Libros: 1433-1444.

Nielsen, S. 2002. 'Lexicographical Basis for an Electronic Bilingual Accounting Dictionary: Theoretical Considerations'. 18 February 2010. http://www.sprog.asb.dk/sn/lexicographicalbasis.htm

Perdiguero, H. 2006. 'La definición de los adverbios de modo en los diccionarios del español' in A. Valencia Espinosa (ed.), XIV Congreso Internacional ALFAL, CD Edition (no pages). Santiago de Chile. http://www.mundoalfal.org/cdcongreso/cd/analisis_estructuras_linguisticas/perdig uero.swf

Porto Dapena, J. A. (2002). Manual de técnica lexicográfica. Madrid: Arco-Libros.

Quirk, R.; Greenbaun, S.; Leech, G. and Svartvik, J. 1985. A Comprehensive Grammar of the English Language. London / New York: Longman.

Renau, I. and Battaner, P. 2010. 'Agrupación semántica de verbos de un DAELE a través de sus relaciones hiperonímicas' in M. A. Castilo Carballo \& J. M. García Platero (eds.), La lexicografía en su dimensión teórica. Málaga: Universidad de Málaga: 543-560.

Renau, I. and Battaner, P. 2011. 'The Spanish Learner's Dictionary DAELE on the Panorama of the Spanish E-lexicography' in I. Kosem and K. Kosem (eds.), Electronic lexicography in the 21st century: new applications for new users. Proceedings of eLex 2011. Trojina: Institue for Applied Slovene Studies: 221226.

Rodríguez Ramalle, M. T. 1999. Algunos aspectos de la sintaxis y la semántica de los adverbios $y$ de ciertas expresiones adverbiales. $\mathrm{PhD}$ Thesis, Universidad Autónoma de Madrid.

Rodríguez Ramalle, M. T. 2003. La gramática de los adverbios en -mente o cómo expresar maneras, opiniones y actitudes a través de la lengua. Madrid: Ediciones de la Universidad Autónoma de Madrid.

Rundell, M. 1988. 'Changing the Rules: Why the Monolingual Learner's Dictionary Should move away from the Native-speaker Tradition' in M. Snell-Hornby (ed.), ZüriLEX '86 Proceedings: Papers read at the Euralex International Congress. Tübingen: A Francke: 127-137.

Schmitt, N. 1998. 'Tracking the Incremental Acquisition of Second Language Vocabulary: A Longitudinal Study'. Language Learning 48: 281-237.

Schmitt, N. and Boyd Zimmerman, C. 2002. 'Derivative Word Forms: What Do Learners Know?'. Tesol Quarterly 36.2: 145-171.

Steyn, M. 2004. 'The Access Structure in Learner's Dictionaries'. Lexikos 14: 275-298.

ten Hacken, P. 2006. 'Word Formation in an Electronic Learners' Dictionary: ELDIT'. International Journal of Lexicography 19.3: 243-256.

Torner, S. 2005a. Aspectos de la semántica de los adverbios de modo en español. $\mathrm{PhD}$ Thesis, Universitat Pompeu Fabra.

Torner, S. 2005b. 'On the Morphological Nature of Spanish Adverbs'. Probus 17.1: 113-142. 
Torner, S. 2007. De los adjetivos calificativos a los adverbios en -mente: semántica y gramática. Madrid: Visor Libros.

Torner, S. 2010. 'La definición de los adverbios en el diccionario monolingüe' in E. Bernal, J. DeCesaris and S. Torner (eds.), Estudis de lexicografia 2003-2005. Barcelona: Institut Universitari de Lingüística Aplicada (Universitat Pompeu Fabra) - Documenta Universitaria: 93-108.

Varela Ortega, S. 1990. Fundamentos de morfología. Madrid: Editorial Síntesis.

Zagona, K. T. 1990. 'Mente Adverbs, Compound Interpretation and the Projection Principle'. Probus 2.1: 1-30. 
Table 1. Adverbs in English dictionaries.

\begin{tabular}{|c|c|c|c|c|c|}
\hline Adverb & Dictionary & Lemmatization & Definition & Examples & Uses VP/S \\
\hline cleverly & $\begin{array}{l}\text { OALD7 } \\
\text { ODE3 } \\
\text { AHD4 } \\
\text { COBUILD6 } \\
\text { MEDAL2 }\end{array}$ & $\begin{array}{l}\text { Sublemma } \\
\text { Sublemma } \\
\text { Sublemma } \\
\text { Sublemma } \\
\text { Sublemma }\end{array}$ & $\begin{array}{l}\text { No } \\
\text { No } \\
\text { No } \\
\text { No } \\
\text { No }\end{array}$ & $\begin{array}{l}\text { No } \\
\text { No } \\
\text { No } \\
\text { Yes } \\
\text { No }\end{array}$ & $\begin{array}{l}- \\
- \\
- \\
\mathrm{VP} \\
-\end{array}$ \\
\hline fast & $\begin{array}{l}\text { OALD7 } \\
\text { ODE3 } \\
\text { AHD4 } \\
\text { COBUILD6 } \\
\text { MEDAL2 }\end{array}$ & $\begin{array}{l}\text { Lemma } \\
\text { Lemma } \\
\text { Lemma } \\
\text { Lemma } \\
\text { Lemma }\end{array}$ & $\begin{array}{l}\text { Yes } \\
\text { Yes } \\
\text { Yes } \\
\text { Yes } \\
\text { Yes }\end{array}$ & $\begin{array}{l}\text { Yes } \\
\text { Yes } \\
\text { Yes } \\
\text { Yes } \\
\text { Yes }\end{array}$ & $\begin{array}{l}\text { VP } \\
V P \\
V P \\
V P \\
V P\end{array}$ \\
\hline happily & $\begin{array}{l}\text { OALD7 } \\
\text { ODE3 } \\
\text { AHD4 } \\
\text { COBUILD6 } \\
\text { MEDAL2 }\end{array}$ & $\begin{array}{l}\text { Lemma } \\
\text { Lemma } \\
\text { Sublemma } \\
\text { Sublemma } \\
\text { Lemma }\end{array}$ & $\begin{array}{l}\text { Yes } \\
\text { Yes } \\
\text { No } \\
\text { No } \\
\text { Yes }\end{array}$ & $\begin{array}{l}\text { Yes } \\
\text { Yes (only S) } \\
\text { No } \\
\text { Yes } \\
\text { Yes }\end{array}$ & $\begin{array}{l}\mathrm{VP} / \mathrm{S} \\
\mathrm{VP} / \mathrm{S} \\
- \\
\mathrm{VP} \\
\mathrm{VP} / \mathrm{S}\end{array}$ \\
\hline intelligently & $\begin{array}{l}\text { OALD7 } \\
\text { ODE3 } \\
\text { AHD4 } \\
\text { COBUILD6 } \\
\text { MEDAL2 }\end{array}$ & $\begin{array}{l}\text { Sublemma } \\
\text { Sublemma } \\
\text { Sublemma } \\
\text { Sublemma } \\
\text { Sublemma }\end{array}$ & $\begin{array}{l}\text { No } \\
\text { No } \\
\text { No } \\
\text { No } \\
\text { No }\end{array}$ & $\begin{array}{l}\text { No } \\
\text { No } \\
\text { No } \\
\text { Yes } \\
\text { No }\end{array}$ & $\begin{array}{l}- \\
- \\
- \\
\mathrm{VP} \\
-\end{array}$ \\
\hline quickly & $\begin{array}{l}\text { OALD7 } \\
\text { ODE3 } \\
\text { AHD4 } \\
\text { COBUILD6 } \\
\text { MEDAL2 }\end{array}$ & $\begin{array}{l}\text { Lemma } \\
\text { Lemma } \\
\text { Sublemma } \\
\text { Sublemma } \\
\text { Lemma }\end{array}$ & $\begin{array}{l}\text { Yes } \\
\text { Yes } \\
\text { No } \\
\text { No } \\
\text { Yes }\end{array}$ & $\begin{array}{l}\text { Yes } \\
\text { Yes } \\
\text { No } \\
\text { Yes } \\
\text { Yes }\end{array}$ & $\begin{array}{l}\text { VP } \\
V P \\
- \\
V P \\
V P\end{array}$ \\
\hline sadly & $\begin{array}{l}\text { OALD7 } \\
\text { ODE3 } \\
\text { AHD4 } \\
\text { COBUILD6 } \\
\text { MEDAL2 }\end{array}$ & $\begin{array}{l}\text { Lemma } \\
\text { Lemma } \\
\text { Sublemma } \\
\text { Sublemma } \\
\text { Lemma }\end{array}$ & $\begin{array}{l}\text { Yes } \\
\text { Yes } \\
\text { No } \\
\text { No } \\
\text { Yes }\end{array}$ & $\begin{array}{l}\text { Yes } \\
\text { Yes } \\
\text { No } \\
\text { Yes } \\
\text { Yes }\end{array}$ & $\begin{array}{l}\mathrm{VP} / \mathrm{S} \\
\mathrm{VP} / \mathrm{S} \\
- \\
\mathrm{VP} / \mathrm{S} \\
\mathrm{VP} / \mathrm{S}\end{array}$ \\
\hline unhappily & $\begin{array}{l}\text { OALD7 } \\
\text { ODE3 } \\
\text { AHD4 } \\
\text { COBUILD6 } \\
\text { MEDAL2 }\end{array}$ & $\begin{array}{l}\text { Lemma } \\
\text { Lemma } \\
\text { Sublemma } \\
\text { Lemma } \\
\text { Sublemma }\end{array}$ & $\begin{array}{l}\text { Yes } \\
\text { Yes } \\
\text { No } \\
\text { Yes } \\
\text { No }\end{array}$ & $\begin{array}{l}\text { Yes } \\
\text { Yes (only S) } \\
\text { No } \\
\text { Yes } \\
\text { No }\end{array}$ & $\begin{array}{l}\mathrm{VP} / \mathrm{S} \\
\mathrm{VP} / \mathrm{S} \\
- \\
\mathrm{S} \\
-\end{array}$ \\
\hline
\end{tabular}


disminuir $\mathrm{v}$. Hacerse menor

1. Una cifra, magnitud, cualidad, sentimiento $\mathrm{u}$ otra cosa, especialmente no material, disminuye cuando se hace menor en cantidad, número, tamaño o intensidad.

En las últimas décadas la mortalidad ha disminuido de forma notoria.

La influencia que el Sol ejerce sobre los planetas disminuye con la distancia.

La lesión intracraneal había disminuido de tamaño.

2. Una persona, una acción, una sustancia bioquímica u otra cosa disminuyen algo no material, como una cifra, magnitud, cualidad o sentimiento, cuando la hacen menor en cantidad, número, tamaño o intensidad.

El suplemento de vitamina $C$ disminuye los síntomas del catarro común.

Todos podemos contribuir efectivamente a disminuir el número de accidentes conduciendo en forma adecuada y correcta.

El ejercicio disminuye las consecuencias negativas del estrés.
Semantic gloss of core meaning

Intransitive sense definition

Examples illustrating syntactic construction

Transitive sense definition

Figure 1. Lexicographical article of a verb in DAELE 